\title{
Cytocompatibility of implants coated with titanium nitride and zirconium nitride
}

\author{
Prachar $\mathrm{P}^{1}$, Bartakova $\mathrm{S}^{1}$, Brezina $\mathrm{V}^{1}$, Cvrcek L ${ }^{2}$, Vanek $\mathrm{J}^{1}$ \\ Clinic of Stomatology, FM MU and St. Anne's University Hospital Brno, Czech Republic. \\ patrik.prachar@fnusa.cz
}

\begin{abstract}
Introduction: The positive cell response to the implant material is reflected by the capacity of cells to divide, which leads to the tissue regeneration and osseointegration. Technically pure titanium and its alloys are mostly used for implant manufacturing. These alloys have the adequate mechanical, physical and biological properties; nevertheless, the superior biocompatibility of bioceramics has been proven. With the arrival of new coating techniques, surface modification of materials used for implants has become a widely investigated issue. Methods: The paper studied properties of titanium nitride (TiN) and zirconium nitride ( $\mathrm{ZrN}$ ) coatings deposited by PVD (Physical Vapour Deposition). Coatings were applied to substrates of pure titanium, Ti6Al4V, Ti35Nb6Ta titanium alloys and CoCrMo dental alloy. Different treatments of substrate surfaces were used: polishing, etching and grit blasting. Cytocompatibility tests assessed the cell colonization and their adherence to substrates. Results and conclusion: Results showed that TiN layers deposited by PVD are suitable for coating all substrates studied. The polished samples and those with TiN coating exhibited a higher cell colonization. This coating technique meets the requirements for the biocompatibility of the implanted materials; furthermore, their colour range solves the issue of red aesthetics in oral implantology as the colour of these coatings prevents titanium from showing through the gingiva. This is one the most important criteria for the aesthetic success of implant therapy (Tab. 5, Ref. 18). Text in PDF www.elis.sk.

Key words: titanium nitride and zirconium nitride coatings, cytocompatibility, bioceramics.
\end{abstract}

\section{Introduction}

In implantology, physical and chemical properties of materials play an important role. The strength of the material in the given dimension with respect to the reduced diameter of an implant while keeping the mechanical and physical properties is very important. Biocompatibility and in this case namely cytological properties are extremely important. In addition, the interaction between cells and the surface of the tested material plays an important role together with the question whether the basic physiological functions, i.e. capacity of the cytoskeleton to regenerate after the inoculation and capacity of cells to divide, have not been damaged. The character of the cell-material interaction may be manifested variously, not only as described in the relevant testing standards (10). The material may be neither cytotoxic nor it exhibits any mutagenic behaviour (clastogenic effect or positive gene tests) and still it may be unsuitable due to the disrupted relationship between the cells and the tested material. It depends on how the cells accept the material or material surface, how the cytoskeleton cells respond in terms of the cytoskeleton regeneration, and if the cell response to the material is positive, and to what extent cell division is maintained or limited. These are the principle parameters roughly indicating the osseointegration capacity.

${ }^{1}$ Clinic of Stomatology, FM MU and St. Anne's University Hospital Brno, Czech Republic, and ${ }^{2} \mathrm{HVM}$ Plasma Ltd. Prague, Czech Republic

Address for correspondence: P. Prachar, MD, PhD, Clinic of Stomatology, St. Anne's University Hospital Brno, Pekarska 53, CZ-659 14 Brno, Czech Republic. Phone: +420.5.43183407

Acknowledgement: This study was based on the project SVC no. 1M0528
Further, we have a possibility to modify the surface of implant materials $(2,8,11)$. In terms of biocompatibility, bioceramics has been confirmed to be a more suitable material than widely used technically pure titan or its alloys $(1,4,6,7)$. The material used previously was, for example, hydroxyapatite applied on metal implants. In a long-term perspective, the adhesion of the hydroxyapatite coating layer was not sufficient (3). The method for depositing coatings has been innovated. The PVD (Physical Vapour Deposition) method is one of possible techniques for coating biocompatible materials. This technique enables to form a nearly perfectly adhering layer of a material (adhesion 1), which does not disintegrate nor affects the surface topography (so important in implantology) $(9,12,16)$. This methods allows to form a layer or layers in orders of microns, in case of hydroxyapatite, a degradable layer accelerating bone healing - osseointegration, can be formed. A number of materials based on hydroxyapatite, carbon, nitrides and other materials exist. This surface modification can change the core, i.e. the material forming the basis for the implant, to a biologically improved material achieving higher criteria of implant healing, i.e. upgrade osseointegration to biointegration. Titan and zirkon nitrides belong to the materials already tested for their mechanical and physical and biological properties. The issue to be solved currently is how to use these materials for different "cores" of materials $(13,17,18)$.

\section{Methods}

Methods for sample surface modification: Samples were prepared from several materials: technically pure titanium, titanium 
alloy Grade V (Ti6A14V), beta-titanium alloy (Ti35Nb6Ta) and chrome-cobalt alloy (CrCoMo) as cylinders with a diameter of $8 \mathrm{~mm}$ and height $3 \mathrm{~mm}$. Surfaces of the experimental cylinders were then modified. Sample surface modifications are shown in the Table 1. Front areas of substrates were ground and then from all sides modified as required according to experimental variants: by polishing, etching, or grit blasting with aluminum oxide (A12O3) grit 120 mesh. The individual variants were split into two groups: one coated with the layer of titanium nitride ( $\mathrm{TiN})$, the other with zirconium nitride $(\mathrm{ZrN})$. TiN / ZrN coatings were deposited with the PVD (Physical Vapour Deposition) using the CAE method (Cathodic Arc Evaporation) (Tab. 1).

Cellular material: The cell line MG 63 (ECACC - European collection of cell cultures - cat. no. 86051601) from osteosarcoma is usually used for testing the implant materials. Its morphology is epithelial without more pronounced cell locomotion. It was cultivated in DMEM supplemented with foetal bovine serum (10\%), antibiotics and antimycotics. Cultures were maintained at $37^{\circ} \mathrm{C}$ in a $5 \% \mathrm{CO}_{2}$ air atmosphere.

The aim of the tests was to compare the capacity of the cell line to colonize the surface of the tested materials after 48 hours of cultivation. The cell population was planted directly on the tested material placed in wells of the cultivation plate (NUNC). The whole experiment was conducted in the same 24 -well plate. Table

Tab. 1. Experimental groups of samples and their modification.

\begin{tabular}{|c|c|c|c|}
\hline Sample no. & Substrate & Modification & Coating \\
\hline 1 & $\mathrm{Ti}$ & $\mathrm{P}$ & TiN \\
\hline 2 & & $\mathrm{E}$ & $\mathrm{TiN}$ \\
\hline 3 & & B & $\mathrm{TiN}$ \\
\hline 4 & & $\mathrm{P}$ & $\mathrm{ZrN}$ \\
\hline 5 & & $\mathrm{E}$ & $\mathrm{ZrN}$ \\
\hline 6 & & B & $\mathrm{ZrN}$ \\
\hline 7 & Ti6Al4V & $\mathrm{P}$ & $\mathrm{TiN}$ \\
\hline 8 & & $\mathrm{E}$ & TiN \\
\hline 9 & & B & TiN \\
\hline 10 & & $\mathrm{P}$ & $\mathrm{ZrN}$ \\
\hline 11 & & $\mathrm{E}$ & $\mathrm{ZrN}$ \\
\hline 12 & & B & $\mathrm{ZrN}$ \\
\hline 13 & Ti35Nb6Ta & $\mathrm{P}$ & $\mathrm{TiN}$ \\
\hline 14 & & $\mathrm{E}$ & $\mathrm{TiN}$ \\
\hline 15 & & $\mathrm{~B}$ & TiN \\
\hline 16 & & $\mathrm{P}$ & $\mathrm{ZrN}$ \\
\hline 17 & & $\mathrm{E}$ & $\mathrm{ZrN}$ \\
\hline 18 & & $\mathrm{~B}$ & $\mathrm{ZrN}$ \\
\hline 19 & CrCoMo & $\mathrm{P}$ & TiN \\
\hline 20 & & $\mathrm{E}$ & $\mathrm{TiN}$ \\
\hline 21 & & B & $\mathrm{TiN}$ \\
\hline 22 & & $\mathrm{P}$ & $\mathrm{ZrN}$ \\
\hline 23 & & $\mathrm{E}$ & $\mathrm{ZrN}$ \\
\hline 24 & & $\mathrm{~B}$ & $\mathrm{ZrN}$ \\
\hline
\end{tabular}

Tab. 2. Scheme of the experimental cultivation.

\begin{tabular}{lcccccc}
\hline & \multicolumn{6}{c}{ Coating } \\
\cline { 2 - 7 } Substrate & TiN & TiN & TiN & ZrN & ZrN & ZrN \\
\hline Ti & P & E & B & P & E & B \\
Ti6A14V & P & E & B & P & E & B \\
Ti35Nb6Ta & P & E & B & P & E & B \\
CrCoMo & P & E & B & P & E & B \\
\hline
\end{tabular}

$\mathrm{P}$ - polished substrate, $\mathrm{E}$ - etched substrate, $\mathrm{B}$ - grit-blasted substrate
Tab. 3. Cell colonization of the modified sample surface with a studied coating in percents.

\begin{tabular}{cc}
\hline Sample no. & Cell colonization $\%$ \\
\hline 1 & 56.72 \\
2 & 55.84 \\
3 & 48.13 \\
4 & 46.58 \\
5 & 47.37 \\
6 & 38.14 \\
7 & 58.03 \\
8 & 56.28 \\
9 & 49.43 \\
10 & 45.23 \\
11 & 43.12 \\
12 & 39.44 \\
13 & 54.31 \\
14 & 56.18 \\
15 & 49.15 \\
16 & 48.83 \\
17 & 46.28 \\
18 & 40.62 \\
19 & 53.64 \\
20 & 51.22 \\
21 & 47.97 \\
22 & 46.97 \\
23 & 45.12 \\
\hline
\end{tabular}

2 shows the scheme of the plate arrangement. After cultivation, the cells were fixed with acetic acid-alcohol and stained to distinguish a border between the cell and material. Then the area occupied by cells in 32 fields of view in the incident light microscope was determined. Fields of view were chosen randomly by scanning. The evaluation was performed from photographic records (Tab. 2).

\section{Results}

Results are given in percentages for the individual alloys, TiN or $\mathrm{ZrN}$ surface coatings, and finally according to substrate modification before coating, i.e. polished, etched, or blasted substrate. The results are summarized in the Table 3 as a percentage of the area colonized by cells for the individual experimental variants. From tables it is evident that in the group with TiN coating, the lowest value $(47.97 \%)$ was recorded in the blasted surface of cobalt chromium (as anticipated) and the highest value $(58.03 \%)$ in the polished surface of titanium alloy Grade $\mathrm{V}$. In the $\mathrm{ZrN}$ coating, the lowest value $(37.65 \%)$ was in the blasted surface of chromium cobalt alloy (again as anticipated), and the highest value (48.83\%) was in the polished surface of beta-titanium alloy. The effect of coating of the modified substrate showed interesting results: the comparison of TiN (Tab. 4) and ZrN (Tab. 5) was in favour of the TiN coating.

Table 3 shows the summarized results of the areas colonized by cells in all samples according to sample numbers and surface modifications given in the Table 1. At first sight it is evident that the individual variants do not differ dramatically, the effect of the substrate modification is more pronounced. Therefore, the experimental variants were split both according to the substrates and their modification and according to the coating with the tested TiN or $\mathrm{ZrN}$ layers (Tabs 4 and 5). A more pronounced difference in the cell coloniza- 
Tab. 4. Colonization of the sample area with cells in percents in titanium nitride coating.

\begin{tabular}{lccc}
\hline & \multicolumn{3}{c}{ TiN coating } \\
\cline { 2 - 4 } Substrate & $\mathrm{P}$ & $\mathrm{E}$ & $\mathrm{B}$ \\
\hline $\mathrm{Ti}$ & 56.72 & 55.84 & 48.13 \\
Ti6Al4V & 58.03 & 56.28 & 49.43 \\
Ti35Nb6Ta & 54.31 & 56.18 & 49.15 \\
CrCoMo & 53.64 & 51.22 & 47.97 \\
\hline
\end{tabular}

$\mathrm{P}$ - polished substrate, $\mathrm{E}$ - etched substrate, $\mathrm{B}$ - grit-blasted substrate

Tab. 5. Colonization of the sample area with cells in percents in zirconium nitride coating.

\begin{tabular}{lccc}
\hline & \multicolumn{3}{c}{ ZrN coating } \\
\cline { 2 - 4 } Substrate & $\mathrm{P}$ & $\mathrm{E}$ & $\mathrm{B}$ \\
\hline Ti & 46.58 & 47.37 & 38.14 \\
Ti6A14V & 45.23 & 43.12 & 39.44 \\
Ti35Nb6Ta & 48.83 & 46.28 & 40.62 \\
CrCoMo & 46.97 & 45.12 & 37.65 \\
\hline
\end{tabular}

$\mathrm{P}$ - polished substrate, $\mathrm{E}$ - etched substrate, $\mathrm{B}$ - grit-blasted substrate

tion of the sample area was recorded in coating with the TiN, compared to $\mathrm{ZrN}$. The tables also show the effect of substrate modification before coating. It is evident that the glossy surfaces are better accepted by cells than the rougher blasted ones (Tabs 3, 4 and 5).

\section{Discussion}

The materials used in implantology must meet the criteria for mechanical and physical resistance $(1,5,15,17)$. In addition, biological properties or biocompatibility are crucial $(4,5,7,9,12,16)$ for successful osseointegration (a fast connection between the material of an implant and bone) or biointegration ensuring a cell-material bond. Until recently, the situation was not fully optimal. The problem was not in a good choice of ceramics-hydroxyapatite - for coating but rather in the technique of adhesion of the material as the coating degraded after some years. Currently, there is an effort to achieve the adhesion of the material marked as $1-$ i.e. the highest possible in scale of the assessment of the surface adhesion (9). The PVD method is one of possible techniques for depositing coatings while maintaining the supreme mechanical and physical properties of the surface layer. This method not only allows to achieve adhesion 1 , it also ensures that surface modification before coating is not damaged $(13,14,18)$ and the topography of the implant material is not altered by coating. The coating material exactly copies the surface and it can be deposited in only a few micrometers thick layers. These findings have also been proven within the grant project (Vaněk, Prachár, Bartáková) studying TiN and ZrN coatings on the chromium cobalt alloy.

\section{Conclusion}

We can conclude that the cellular adhesion is significantly affected by the type of the implant material and its surface modification. In the group of TiN coating, the best material was the titanium Grade $\mathrm{V}$ alloy in polished treatment and the worst was blasted chromium cobalt alloy. In the group of $\mathrm{ZrN}$ coating, betatitanium alloy with polished modification was assessed as the best and chromium cobalt alloy in the blasted surface was the worst.
Further important finding was the difference in cell colonization in favour of the polished surface versus the blasted surface and a higher cell colonization in samples with the TiN coating compared to those with $\mathrm{ZrN}$ coating. All these findings confirm suitability of the use of $\mathrm{TiN}$ and $\mathrm{ZrN}$ coating materials in implantology.

\section{References}

1. Abraham JA, Grenón MS, Sánchez HJ, Pérez CA, Valentinuzzi MC. Titanium based implants, metal release study in the oral environment LNLS 2006 Activity Report.

2. Baril E, Lefebvre L.P, Yannig T, Florin I. Foam-coated MIM gives new edge to titanium implants. Metal Powder Report 2008; 63 (8): 46-50.

3. Dostálová T, Himmlová L. Osseointegration of loaded dental implant with $\mathrm{KrF}$ laser hydroxylapatite films on Ti6Al4V alloy by minipigs. J Biomed Opt 2001; 6: 236. DOI:10.1117/1.1357191.

4. Geurtsen W. Biocompatibility of dental alloys. Crit Rev Oral Biol Med 2002; 13 (1): 71-84.

5. Kudrman J, Chlubnová R, Veselý J. Hnilica F, Podhorná B. Properties of titanium beta alloys suitable for use in human medicine. Book of abstracts. Metal 2008, Hradec nad Moravicí.

6. Niespodziana K, Jurczyk K, and Jurczyk M. The synthesis of titanium alloys for biomedical applications. Rev Adv Mater Sci 2008; 18: 236-240.

7. Niinomi M. Recent research and development in titanium alloys for biomedical applications and healthcare goods. Sci Technol Adv Mater 2003; 4 (5): s. 445-454.

8. Petruželka J, Dluhoš L, Hrušák D, Sochová J. Nanostructured titanium application in dental implants. In: Abstract Booklet of the International Conference NANO'06, Brno University of Technology, 1, 2006, s. 100.

9. Prachár P, Vaněk J, Cvrček L, Bartáková S. Characteristics of surface layer of chromium cobalt alloy coated with titanium nitride and zirconium nitride. Prakt Zub Lék 2005; 53 (4): 65-67.

10. Červinka M, Půža V. In vitro toxicity testing of implantation materials used in medicine: effects on cell morphology, cell proliferation and DNA synthesis. Toxicol Vitro 1990; 4 (4/5): 711-716.

11. Rimondini L, Fare S, Brambilla E, Felloni A, Consonni C, Brossa F, Carrassi A. The effect of surface roughness on early in vivo plaque colonization on titanium. J Periodontol 1997; 68: 555-556.

12. Silvennoinen R, Vetterl V, Hasoň $S$, Tuononen H, Silvennoinen M, Miller K, Cvrček L, Vaněk J, Prachár P. Sensing of human plasma fibrinogen on polished, chemically etched and carbon treated titanium surfaces by diffractive optical element based sensor. Optics Express 2008; 16 (14): 101-130.

13. Shimakura M. Efficient polishing method of titanium. J Soc Titanium Alloys in Dent 2007; 5: 32-33.

14. Tajima T, Hironaka M, Chen K, Nagamatsu Y,Kakigava H, Kozono Y. Electropolishing of CP titanium and its alloys in an alcoholic solution-based electrolyte. Dent Mater J 2008; 27 (2): 258-265.

15. Takada Y, Nakajima H, Okuno O, Okabe T. Microstructure and corrosion behavior of binary titanium alloys with beta-stabilizing elements. Dent Mater J 2001; 20: 34-52.

16. Vaněk J, Prachár P, Bartáková S, Březina V, Freyburg L. Biological tests of chromium - cobalt alloy coated with titanium nitride and zirconium nitride. Čes Stom 2005; 105 (6): 149-153.

17. Yamamuro T. Patterns of osteogenesis in relation to various biomaterials. J Jpn Soc Biomater 1989; 7: 19-23.

18. Yoshinari M, Oda Y. Titanium surface modification with dry process for dental implants. 129-136. In: Niinomi M, Okabe T, Taleff EM, Lesuer DR, Lippard HF (Eds). Structural Biomaterials for the 21st Century, TMS, 2001.

Received November 11, 2013. Accepted May 16, 2014. 